\title{
Bacteriological studies on mastitis in dairy Friesian cattle in Quena governorate
}

\author{
Z. M. Sayed ${ }^{1}$, A. E. A Mohamed ${ }^{2}$ \\ ${ }^{1}$ Animal Health Research Institute Quena, Regional Laboratory and ${ }^{2}$ Animal medicine college of \\ Veterinary Medicine, South Valley University, Quena, Egypt.
}

\begin{abstract}
Fifty five milk samples were collected from dairy Friesian cows suffering from clinical mastitis in a farm at Quena Governorate. The samples were subjected to microbiological examination .The main isolated pathogenic bacteria were identified biochemically as Escherichia coli $(36.3 \%)$, Staphylococcus aureus (23.6\%) Streptococcus agalactiae (18.2\%), Klebsiella pneumoniae (12.7\%) and bacterial free samples $(9.1 \%)$. Sensitivity tests for the bacterial isolates revealed that the tested strains were sensitive to ciprofloxacin, nortril, gentamicin and lincospectin.
\end{abstract}

Mastitis is one of the most significant problems in dairy herds and responsible for extended usage of antibiotics in these enterprises (Kromker and Greboski, 2002). Bovine mastitis is an inflammation of the mammary glands, usually due to a microbial infection and considered to be the worldwide costliest production disease in dairy herds (Miller et al., 1993 and Rainard et al., 2003). Mastitis is considered of vital importance due to its association with many zoonotic diseases in which milk acts as a source of infection (APHA, 1993). Bovine mastitis is caused by various bacteria, mycoplasma and fungi ( Bourry et al., 1997; Jones et al., 1997) and it resembles urinary tract infection as both are ascending caused by bacteria from the environment (Bocdeker , 2005)

The present work aimed to study the causative agents of mastitis in dairy Friesian cattle in Quena Governorate and sensitivity of the isolated organisms to different antibiotics.

\section{Materials and methods}

Milk samples. Fifty five milk samples were collected from dairy Friesian cattle at a farm in Quena Governorate showing clinical signs of mastitis. The samples were taken under aseptic condition and transferred in an ice box to the laboratory.

Bacteriological examination. Milk samples were incubated aerobically at $37^{\circ} \mathrm{C}$ for $24 \mathrm{~h}$ then centrifuged at $3000 \mathrm{rpm}$ for 20 minutes. The supernatant was discarded and a loopful from the sediment was streaked onto the surface of each blood agar and MacConkey agar plates. The plates were incubated at $37^{\circ} \mathrm{C}$ for $24-48 \mathrm{~h}$, and examined for bacterial growth. The isolated colonies were identified by their morphological characters, colonial appearance and then picked up, cultured onto slope agar to obtain pure culture. Biochemically identified according to Chruichshank et al., (1975). Sensitivity tests for bacterial isolates were carried out using the disc diffusion methods of susceptibilty test according to ( Quinn et al., 1994 ). The antibacterial discs were supplied by (Oxoid) with different concentrations including ciprofloxacin $(30 \mu \mathrm{g})$, rifampicin $(5 \mu \mathrm{g})$, doxycylline $(30 \mu \mathrm{g})$, nortril

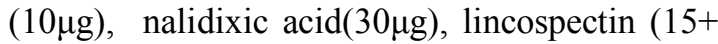
$200 \mu \mathrm{g})$, sterptomycin $(10 \mu \mathrm{g})$, colistin sulphat $(10 \mu \mathrm{g})$, gentamicin $(10 \mu \mathrm{g})$, and flumequine $(10 \mu \mathrm{g})$ were used. The medium used in sensitivity tests was nutrient agar (Oxoid) (CM0003) Lot/ 345492.

\section{Results}

Isolation and identification of the isolated organisms. The bacteriological examinations of the milk samples collected from mastitic cattle revealed the presence of Escherichia coli, Staphylococcus aureus, Streptococcus agalactiae and Klebsiella pneumoniae organisms with variable rates as shown in Table (1).

\section{Discussion}

Bovine mastitis is a major disease that affect dairy industry and E.coli is one of the most frequently isolated pathogens from both clinical and chronic infections (Bramley et al.,1996).The most dominant bacteria in the present study as shown in Table (1) were E.coli followed by S.aureus, S.agalactiae, and K. pneumoniae in ratio of $36.36 \%, 23.63 \% 18.18 \%, 12.72 \%$, 
Table (1): Microorganisms isolated from examined samples.

\begin{tabular}{lcc}
\hline Microorganisms & No. of strains & Percentage \% \\
\hline Escherichia coli & 20 & $36.36 \%$ \\
Staphylococcus aureus & 13 & $23.63 \%$ \\
Streptococcus agalactae & 10 & $18.18 \%$ \\
Klebsiella pneumoniae & 7 & $12.72 \%$ \\
Bacterial free samples & 5 & $9.10 \%$ \\
\hline
\end{tabular}

Table (2): Antibacterial sensitivity tests of isolated organisms.

\begin{tabular}{|c|c|c|c|c|c|c|c|c|c|c|}
\hline & 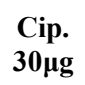 & $\begin{array}{c}\text { Lin. } \\
15+200 \mu g\end{array}$ & 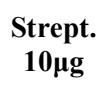 & $\begin{array}{l}\text { Gen. } \\
10 \mu g\end{array}$ & $\begin{array}{l}\text { Nor. } \\
10 \mu \mathrm{g}\end{array}$ & $\begin{array}{l}\text { Colis. } \\
\text { 10ug }\end{array}$ & $\begin{array}{l}\text { Flum. } \\
10 \mu g\end{array}$ & 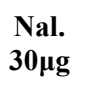 & 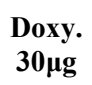 & $\begin{array}{l}\text { Rif. } \\
5 \mu \mathrm{g}\end{array}$ \\
\hline E. coli & +++ & +++ & - & +++ & +++ & - & ++ & + & + & + \\
\hline Staph. aureus & +++ & +++ & - & ++ & +++ & - & + & + & + & + \\
\hline S. agalactiae & +++ & +++ & - & ++ & +++ & - & + & + & + & + \\
\hline K. рпеитопіае & ++ & ++ & _ & ++ & ++ & + & + & + & + & + \\
\hline
\end{tabular}

$+++=$ Sensitive $\quad++=$ Intermediat $\quad---=$ Resistant

Cip: Ciprofloxacin Lin: Lincospectin Strep.: Streptomycin Gen.: Gentamicin Not.: Nortril Colis.: Colistin sulphat, Flum.: Flumequine, Nal.: Nalidixic acid ,Doxy.: Doxycycline, Rif.: Rifampicin.

respectively while bacterial free samples were $9.1 \%$. This result agreed with that recorded by (Gregory and Hoedemaker, 2002; Ahmed et al., 2006) who recorded that most of clinical mastitis in cattle originated from E.coli followed by S.aureus, S.agalactiae, and K. pneumoniae in ratio of $51.1 \%, 20.7 \%, 18.5 \% 6.5 \%$, respectively .It was also reported that the incidence of isolation of E.coli was $21.05 \%$ while $K$. pneumoniae was $6.75 \%$ from mastitic dairy buffaloes (Ahmed et al.,1988; Shalaby and Salem, 2001). El-Mahrouki et al., (2006) recorded that, E.coli isolates from mastitis usually posses one or more virulence properties that may help in establishment at the infection site and subsequently causing a disease condition. Saddek et al.,(1999) found that the main causative bacterial agent responsible for subclinical mastitis in dairy cows were $S$. aureus ,E.coli, S. epidermids, S. agalactiae, Corynebacteruim bovis , $S$. dysagalactiae and Citrobacter in ratio of $29.10 \%, 20 \%, 18.20 \%, 12.7 \%$, $10.90 \%, 5.46 \%, 3.64 \%$, respectively and these results agree with the obtained results. Staphylococci are widely distributed in nature as they can grow in any food article if the conditions are suitable .The most important species of Staphylococcus are S.aureus due to their pathogenicity and their ability for enterotoxin production (Tsung and Huang, 1993). Sayed (1996) mentioned that the main bacterial causes of mastitis were E.coli, S.ubris, K. pneumoniae and Corynbacterium bovis, which were recovered from $41.6 \%, 22.2 \%$, $22.2 \%$ and $13.9 \%$ of total examined samples respectively. The ability of staphylococci to survive in phagocytes and mammary epithelial cells results in the persistence of infection and development of botryomycosis (Jones et al.,1997; Diawa et al., 2003). The results of sensitivity tests using different antibacterial discs cleared that the isolated organisms were sensitive to ciprofloxacin, nortril, gentamicin and lincospectin.

\section{References}

Ahmed, E. A.; Abd El-Sangary, H. A. and Abou Zead, A.A. (2006): Bacterial and biochemical studies on mastitis 
of cattle in Sharkia Governorate Assiut Vet. Med. J., 52(109):207-214.

Ahmed, O. ; Michel, G.; Mounce, D. and Jeep, P. (1988): Virulence factor and markers in Escherichia from calves with diarrhoea .Am.J.Vet .Res., 49(10):1657-1660.

APHA "American Public Health Association "(1993): Compendium of Methods for the Microbiological Examination of Foods .INC. $4^{\text {th }}$ ed. New York.

Bocdeker, E. C. (2005): Vaccines for enterotoxigenic Escherichia coli: current status. Curr Opin Gastroenterol., 21 (1): 15-19.

Bourry, A.; Cochard, T. and Poutrel, B. (1997): Serological diagnosis of bovine, caprine and ovine mastitis caused by listeria monocytogenes by using an ELISA. J. Clin. Microbiol., 33: 6.

Bramley, A. J. ; Harmon , J. ; Smith , K. L. and Hogan , J.S. (1996) : Current Concept of bovine mastitis , 4 ed. The National mastitis Council Walton Commons West, Masdison , w/53704 (608):224-622 .

Cruickshank, R.; Dugid, J. R.; Marmion, B. P. and Swain, R. H. A. (1975): Medical Microbiology :The practice of medical microbiology $.12^{\text {th }}$ ed. Vol.2, Churchill ,Livingestone, London.

Diawa , M. S.; Petitcher, D.; Deschenes, E.N.; Grondin, G.; Talbot, B. and Lacasse P. (2003) :Lactoferrin against Staphylococcus mastitis, lactoferrin alone or in combination with penicillin G. on bovine polymorphomuclear function and mammary epithelial cells colonization by Staphylococcus aureus. Vet. Immunol. Immunopathol., 95: 33-42.

El-Mahrouki, A. M.; Nevine, M. Sobhy and Aggour, M.G. (2006) : Detection of Coliform mastitis in cattle with special refernce to molecular characterization of enterotoxigenice E.coli using polymerase chain reaction (PCR) .J. Egypt Vet. Med. Assoc., 66(1)47-58.

Gregory, A. and Hoedemaker, M. (2002) : Bovine catarrhal mastitis ,frequency, etiology and therapy .In the proceeding of the ХXП world Buiatrics congress ,18-23 August 2002,Hannover Germany.

Jones, T.; Hunter R. and King N. (1997): Veterinary pathology. $6^{\text {th }}$ ed. Williams and Wilkins Awavery company, Baltimore, Philadelphia, London.

Kromker,V. and Grobowski, N.T.(2002) : Risk factor analysis for mastitis caused by environmental pathogens in the environment of dairy herds . In the Proceeding of XXП World. Buiatrics congress, Hannover, Germany, 18-23 August 2002. pp 141.

Miller, R. H.; Pape, M.J.; Futton, L. A. and Schtz, M. M. (1993): The relationship of milk and somatic cell count to milk yeilds for Holistein heifers after first calving. J. Dairy Sci., 76:728-733.

Quinn, P.J.; Carter, M.E.; Markey, B.K. and Carter (1994): Clinical Veterinary microbiology. Mosby-Year Book Europe Limited London England $1^{\text {st }}$ Ed.

Rainard, P.; Corrales, J.C.; Barrio, M.B.; Cochard , T. and Poutrel B. (2003): Leukcytic activaties of Staph.aureus strains isolated from cows, ewes, and goats with mastitis. Clin. Diag. Immunol., 10 (2):272-277.

Saddek, S.R.; Abd El-Kader, H.A. and Abd El-Haffeez, M.M. (1996): Bacteriological studies of subclinical mastitis in friesian cattle in assuit Governorate . Assiut Vet.Med. J., 42 (83):77-88.

Sayed, A.M. (1996): Bacterial causes and antibiogram of mastitis in dairy friesian cows at Assiut Governorate. Assiut Vet. Med. J., 34(68):22-29.

Shalaby, B. and Salem, R.M.T. (2001): Bacteria and fungi as probable of mastitis in dairy buffaloes. J. Egypt Vet. Med. Assoc., 61 (3): 137-144 .

Tsung , C. and Huang, S. (1993) : An immune linked immunosorbant assy for rapid detection of $S$. aureus in processed food. J. Food Prot., 75 (3):184-18 .

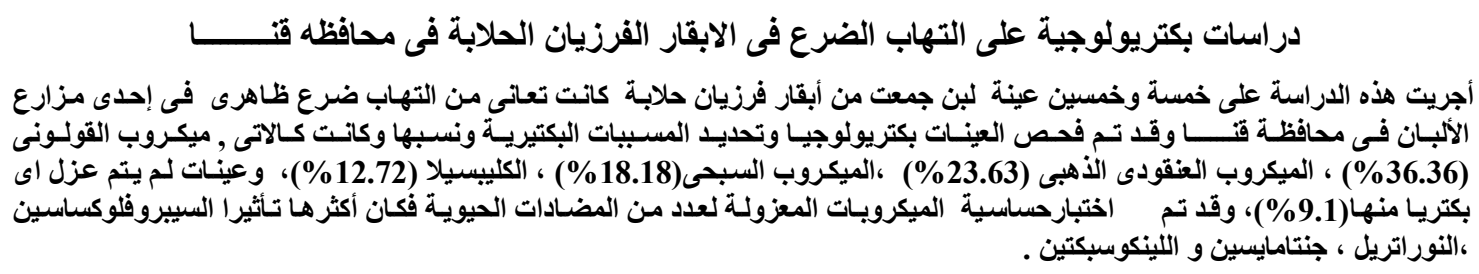

